Published in International journal of contemporary hospitality management, 2016, vol.28 no.9, pp. 1915-1936 which should be cited to refer to this work

\title{
Analysis of satisfiers and dissatisfiers in online hotel reviews on social media
}

\author{
Dr. Bona Kim* \\ Assistant Professor \\ Mount Saint Vincent University, Canada \\ bona.kim2@msvu.ca \\ Dr. Seongseop Sam Kim \\ Associate Professor \\ The Hong Kong Polytechnic University, Hong Kong \\ sam.kim@polyu.edu.hk \\ Dr. Cindy Yoonjoung Heo \\ Assistant Professor \\ Ecole hôtelière de Lausanne \\ HES-SO/ University of Applied Sciences Western Switzerland, Switzerland \\ Cindy.HEO@ehl.ch
}

\section{* Corresponding author}

Dr. Bona Kim can be contacted at: bona.kim2@ msvu.ca 


\title{
Analysis of satisfiers and dissatisfiers in online hotel reviews on social media
}

\begin{abstract}
Purpose - The purpose of this study is to analyze online hotel reviews produced by customers in order to identify and compare factors known as satisfiers and dissatisfiers based on Herzberg's two-factor theory. This approach was applied to compare full-service and limited-service hotels, which can show different levels of customer expectation.

Design/methodology/approach - A content analysis of 919 satisfaction- and dissatisfactionindicating reviews of 100 hotels in both full-service and limited-service hotel segments in New York City on Trip Advisor was conducted.

Findings - Results show that satisfiers and dissatisfiers in full-service hotels were distinct, with the exception of two common service-related factors, namely "staff and their attitude" and "service." On the other hand, "staff and their attitude" and four room facilities-related factors, "room cleanliness/dirtiness," "bed," "bathroom," and "room size," were revealed as common satisfiers and dissatisfiers in limited-service hotels. In order to fulfill customer satisfaction and resolve dissatisfaction in both full-service and limited-service hotels, satisfiers and dissatisfiers should be highlighted according to the hotel class; the most critical factor is "staff and their attitude."
\end{abstract}

Practical implications - Analysis of online hotel reviews provides understanding of customers' satisfiers and dissatisfiers and the results are very useful to hotel management. Therefore, hotel 
operators should monitor electronic word-of-mouth, recognizing and acting upon previous and current customers' satisfactory and unsatisfactory reactions, respectively.

Originality/value - As technologies such as social media develop, customers are increasingly sharing their satisfactory and unsatisfactory experiences on consumer-generated online review sites. These have become a major source of information not only for customers deciding on a hotel stay, but also for hotel managers trying to understand their customers and competitors.

Keywords Social media, Online hotel review, Trip Advisor, Herzberg's two-factor theory, Satisfiers, Dissatisfiers, Customer expectation, Full-service hotel, Limited-service hotel

Paper type Research paper 


\section{Introduction}

Social media-friendly customers are increasingly inclined to report their honest opinions of their service experiences on social networks (Xiang and Gretzel, 2010). Of the diverse social media platforms available, online review websites are recognized as one of the most accessible tools for understanding social media-friendly customers' experiences more precisely (Gretzel and Yoo, 2008; Pantelidis, 2010). These sites have the specific purpose of providing information about hotel stays or destinations as part of the trip planning process (Vermeulen and Seegers, 2008).

To keep pace with customers' use of social media, hotel companies have recently begun to adopt diverse tools such as social media websites, customer-generated content, or online reviews to assist in decision making and as a marketing technique to maximize utilization (Chan and Guillet, 2011; Leung et al., 2013; McCarthy et al., 2010). Researchers in the hospitality field are paying increasing attention to the importance of reviewing social media content to improve the customer experience quality and identify opportunities for service recovery. Reviewing content on social media also helps them to understand customers' satisfaction and dissatisfaction (Berezina et al., 2015; Jeong and Jeon, 2008; Levy et al., 2013; Li et al., 2013).

In the customer behavior literature, understanding customer satisfaction is one of the most popular topics in examining the performance of a service firm (Anderson et al., 1994; Babin and Griffin, 1998; Barsky, 1992). Antecedents leading to hotel customer satisfaction during customers' stay have been identified in previous research in order to assess their perception of service performance (Barsky and Labagh, 1992; Choi and Chu, 2000; Gu and Ryan, 2008; Poon and Low, 2005). On the other hand, customer dissatisfaction is considered in 
order to examine reasons for service failure or deteriorating business profit (Yang and Mattila, 2012). However, it has been neglected to independently recognize the antecedents determining customer dissatisfaction, even though unfavorable outcomes can influence a firm's overall performance more than the positive effects of customer satisfaction (Hoffman and Chung, 1999; Schlossberg, 1991).

According to Herzberg's two-factor theory (Herzberg, 1966; Herzberg et al., 1958), specific factors causing satisfaction do not generate dissatisfaction, and vice versa. In other words, two different sets of satisfiers and dissatisfiers have emerged, showing that the typical statement that satisfiers and dissatisfiers lie on a continuum is a fallacy. Based on this assumption of the two-factor theory, it is essential to understand both customer satisfaction and dissatisfaction through thorough review of customers' written comments on social media, in order to explore customers' needs and wants more closely (Levy et al., 2013; Li et al., 2013). In addition, each customer has his/her own frame of reference with which to evaluate satisfaction or dissatisfaction, which indicates different expectations in different situations. These expectations can vary from a low to a high level depending on the individual's own standards (Miller, 1977). In a hotel setting, customers expect certain standards of services and facilities in different classes of hotel. As a result, the level of customer expectation can substantially affect both customer satisfaction and dissatisfaction in different hotel classes.

In summary, insufficient research efforts have been made to understand customers' satisfactory and unsatisfactory experiences by analysis of online reviews (Levy et al., 2013; Li et al., 2013; Pantelidis, 2010). This study aimed to identify both satisfiers and dissatisfiers by analyzing hotel customers' comments by applying a bi-dimensional approach of Herzberg's two- 
factor theory. This study also attempted to identify how satisfiers and dissatisfiers differ according to the level of customer expectation. The level of expectation was categorized into two levels, high and low. Then satisfiers and dissatisfiers were compared for both hotel segments. Overall, the examination of online hotel reviews is expected to reflect a new social media marketing trend in a social media-friendly customer era, and provide managerial implications for the hotel sector.

\section{Literature review}

\subsection{Social media trends and online hotel reviews}

The diverse impact of social media on tourism and hospitality has been researched from both the customer and management perspectives (Law et al., 2014; Leung et al., 2013). For the customers, since social media provides unique, in-depth, and customer-generated content through interaction with other customers (Wang and Fesenmaier, 2004), studies have examined such content as a resource for decision making and collaborative platform for experience sharing (Pantelidis, 2010; Sparks and Browning, 2011). From the operations and management perspective, social media has emerged as a new and effective marketing tool based on customer interaction (Chan and Guillet, 2011).

One of the most influential social media tools in the hotel industry is online review sites that allow customers to share their experiences and opinions online (Xiang and Gretzel, 2010). Online reviews are recognized as the most accessible and valuable feedback platform in the hospitality business environment because previous customers tend to list their experience, which potential customers review prior to purchasing hotel products (Verma et al., 2012; Yoo and 
Gretzel, 2008). In the information-saturated global community, customers show a high tendency to gather unfiltered information from a large number of other similar customers on cyber network space because they regard online peer review as a more reliable, up-to-date, and trustworthy source than data from immediate service providers (Harwood, 2007; Hennig-Thurau et al., 2004). Consequently, reviews by fellow customers can affect purchase decision making (Gretzel and Yoo, 2008). Therefore, the hotel industry needs to persistently monitor customerreported online reviews in order to calibrate customers' positive and negative experiences (O’Connor, 2010).

Online hotel reviews are one of the most candid information sources that can be utilized to understand why customers are satisfied or dissatisfied because they are based on their actual experiences (Gretzel and Yoo, 2008; Jeong and Jeon, 2008; Levy et al., 2013; Li et al., 2013). For example, as an approach to measuring hotel performance, Jeong and Jeon (2008) analyzed the quantitative rating of nine attributes of hotels in New York City provided by Trip Advisor: room, value, cleanliness, location, check in and check out, service, business service, guests' satisfaction, and intention. These attributes were compared to explore how they differ according to ownership, hotel popularity by star rating, hotel class, and average daily rate. Jeong and Jeon (2008) identified value as the key factor for customer satisfaction and return intention.

However, limited efforts have been made to review online comments to identify factors that lead to customer satisfaction (Berezina et al., 2015; Li et al., 2013; Pantelidis, 2010) and dissatisfaction (Levy et al., 2013). Li and colleagues (2013) also analyzed the satisfiers in online reviews of luxury and budget hotels in Beijing on the Chinese third-party website "daodao.com." However, they did not examine negative comments, despite focusing on the antecedents of 
customer satisfaction. Unlike the above studies on satisfiers, Levy and colleagues (2013) investigated the reasons for complaints by analyzing one-star reviews among comments about Washington, D.C. hotels on ten famous online review websites. They analyzed the complaints in terms of hotel characteristics, reviewer characteristics, purpose of travel, and geographic location. They identified attitude of front desk staff, bathroom, noisiness, and room cleanliness as the major reasons for customer complaints. In the restaurant context, Pantelidis (2010) examined the salient factors determining customers' experience in restaurants listed on the online guide "London-Eating.co.uk." Pantelidis argued that positive and negative comments in cyber reviews should be regarded as equally important because a positive evaluation can help a business secure custom, while negative words can harm the business. From the service recovery perspective, Sparks and Bradley (2014) examined managers' responses to negative Trip Advisor reviews of both high- and low-ranking hotels in Sydney. They discovered that high-ranking hotels' managers tend to answer such reviews with recognition and appreciation, while lowranking hotels' managers tend to make no response or answer such reviews with no elaboration.

Based on reviewing literature on online hotel reviews on social media platforms, few studies have investigated overall factors leading to customer dissatisfaction by comparing with factor leading to customer satisfaction in a hotel setting. Consequently, this study attempted to identify both satisfiers and dissatisfiers through assessing customers' self-reported comments on Trip Advisor in order to understand customers' experience of quality. Based on the Herzberg's two-factor theory, this study proposed an approach of Herzberg's two-factor theory to satisfiers and dissatisfiers. 


\subsection{Satisfiers and dissatisfiers}

It has been widely recognized that customers' satisfaction is determined by their assessment of a hotel's different attributes. As Table I shows, diverse studies have analyzed the factors influencing customer satisfaction (Barsky and Labagh, 1992; Choi and Chu, 2000; Dolnicar and Otter, 2003; Gu and Ryan, 2008; Poon and Low, 2005; Qu et al., 2000). These studies measured customer satisfaction on a range from highly dissatisfied to highly satisfied. However, this approach may not be adequate, for two reasons (Alegre and Garau, 2010). Firstly, since the satisfiers do not include negative features of customers' experiences at a hotel, they ignore the existence of negative features. Secondly, the uni-dimensional concept of satisfiers leading to customer satisfaction is not sufficient to understand customer satisfaction and dissatisfaction as distinct principles.

This implies that the causes of customer dissatisfaction may be different from those of customer satisfaction as a bi-dimensional concept. Thus, some studies conceptualized two separate sets of factors leading to satisfaction and dissatisfaction (Cadotte and Turgeon, 1988; Chan and Baum, 2007; Jones et al., 1997; Maddox, 1981; Swan and Combs, 1976). An extended concept of both satisfaction and dissatisfaction was proposed by Herzberg and colleagues (1958, 1966). Their studies developed the Herzberg's two-factor theory, which states that satisfaction and dissatisfaction are not on the same bipolar continuum where one increases as the other diminishes. That is, satisfaction and dissatisfaction are affected by two independent sets of satisfiers and dissatisfiers, respectively (Herzberg, 1966; Herzberg et al., 1958).

The two-factor theory has been extensively applied to situations of customer satisfaction and dissatisfaction (Babin and Griffin, 1998; Johnston, 1995; Maddox, 1981; Swan and Combs, 
1976). For example, Swan and Combs (1976) found that customer satisfaction and dissatisfaction are two independent concepts which can be accounted for by the gap between the levels of expectation and performance. They referred to satisfaction as "expressive outcomes," which indicates a situation that meets or exceeds customers' expectations. In contrast, dissatisfaction was referred to as "instrumental outcomes" below customers' expectations. Maddox (1981) replicated the study of Swan and Combs (1976) with a larger and more heterogeneous sample drawn from consumers who purchase clothing, personal care, and durable products. The findings showed that the traditional view regarding the existence of both satisfiers and dissatisfiers was inconsistent and dependent on ambiguous items and individuals. Similarly, Johnston (1995) identified distinct sources of satisfaction and dissatisfaction in the context of bank management, finding that satisfiers were linked to interpersonal service features, whereas dissatisfiers were linked to operational or physical features.

In the hospitality literature, Cadotte and Turgeon (1988) carried out a survey of the frequency of compliments and complaints from patrons at 432 restaurants and 260 lodging businesses in the U.S. After analyzing these compliments and complaints, they found four typologies: satisfiers, dissatisfiers, critical attributes, and neutral attributes. Here, the satisfiers represented the factors that gave customers a pleasant surprise with a higher level of performance than expected in the areas of employees' attitude, cleanliness, neatness of establishment, service quality, and employees' knowledge of service. The five dissatisfiers represented necessary and basic conditions of performance in the aspects of room rate, meals, service, speed of service, service quality, parking availability, and employees' knowledge of service. Likewise, Johns and Howard (1998) identified 67 satisfiers and 61 dissatisfiers in a restaurant setting by comparing 
the gap between expectation and perceived performance. They discovered that each attribute can be a satisfier or dissatisfier because satisfaction and dissatisfaction are decided by each individual's subjective perception and purchase circumstances. Focusing on tangibility of attributes, Jones et al. (1997) analyzed 299 items of written feedback from customers at eight small hotels and guesthouses in the U.K. They found that tangible factors were associated with both satisfaction and dissatisfaction, whereas intangible factors were only associated with satisfaction. Similarly, Chan and Baum (2007) found that satisfiers were intangible and dissatisfiers tangible in the eco-lodging setting.

Though it has been argued that the absence of satisfiers does not necessarily lead to and reinforce customer dissatisfaction (Alegre and Garau, 2010), very few studies have examined the determinants of hotel customer dissatisfaction and they only measured the discrepancy between service expectations and perceived performance when they were not delivered to the expected standard (Dolnicar, 2002; Heung, 2000). The hotel attributes which lead to dissatisfaction are listed in Table I.

\section{Table I}

As described above, such findings regarding the identification of satisfiers and dissatisfiers can be inconsistent across different industrial contexts. As a result, there is a need to understand satisfiers and dissatisfiers as separate concepts perceived by hotel customers. Furthermore, it is necessary to identify whether satisfiers and dissatisfiers differ according to 
different levels of customer expectation because customer expectation is an antecedent in individual evaluation of both satisfaction and dissatisfaction.

\subsection{Customer expectation between full-service and limited-service hotels}

Individuals have different levels of expectation in assessing past experience and provision of different services in customer-employee interactions (Miller, 1977). In an initial study, Cardozo (1965) showed that expectation of a product can be defined as a set of guidelines for evaluation and prediction. Thus customer expectation plays a major role in judging satisfaction and dissatisfaction (Anderson and Sullivan, 1993; Oliver, 1980; Oliver and Linda, 1981).

In the hotel management context, customer expectation is formulated differently depending on hotel class. Hotel businesses are willing to pursue differentiation strategies, providing products with specialized features which can distinguish them from other properties (Knutson, 1988). Each hotel class delivers services and facilities at a certain level of quality. These levels of service are likely to lead to diverse customer expectations (Nasution and Mavondo, 2008). Thus, it is feasible for customers to have different levels of expectation of different hotel classes (Knutson et al., 1993). As a consequence, customers' expectation level should be considered to be one of the significant factors in satisfaction and dissatisfaction (Dolnicar, 2002).

Some studies have investigated different theoretical aspects of differentiated customer expectation according to hotel class and found that customers of luxury hotels expect highquality service and a luxurious atmosphere, whereas budget hotel customers expect only minimal 
service that meets their basic needs. (Griffin et al., 1997; Knutson, 1988; Knutson et al., 1993;

Nasution and Mavondo, 2008). To summarize, customer expectation of a hotel rises as the room rate goes up because they are likely to use price as a cue for their expectations in situations where they lack information and prior experience (Knutson et al., 1993). Consequently, the level of customer expectation of a hotel can vary according to hotel class, and may affect customer satisfaction and dissatisfaction levels.

\section{Methodology}

\section{Research setting}

We retrieved customers' comments listed on the hotel review website Trip Advisor, one of the most widely used online review websites by global travelers and the most prominent usergenerated content review sites (O’Connor, 2008; Verma et al., 2012). Hotels in New York City featured on the site were selected as the population of sample for this study. First, New York, the biggest metropolitan city in the US, is one of the most popular tourism destinations in the world (Gladstone and Fainstein, 2001). Second, it is also home to a large number of lodging businesses representing a diversity of hotel classes ranging from luxury, upscale, and mid-scale, to economy (Jeong et al., 2003).

\section{Data collection procedure}

Satisfaction- and dissatisfaction-indicating hotel reviews relating to two different hotel classes were considered for analysis. In order to enhance reliability and validity of this study, data collection and analyses followed several steps. In the first step, in order to identify 
satisfaction- and dissatisfaction-indicating reviews, this study referred to Trip Advisor's guidelines. Travelers' ratings on the Trip Advisor website are designed to indicate an overall evaluation of their hotel stay experience using a five-point Likert type scale from (1) "terrible", to (2) "poor", (3) “average", (4) "very good", and (5) “excellent." This rating is a reliable assessment outcome for this study because customers can evaluate their overall hotel stay and leave comments on one of the five-point ratings.

In this study, positive comments belonging to the "excellent" category were analyzed to identify satisfiers and defined as "satisfaction-indicating reviews," while negative reviews in the "terrible" category were analyzed to investigate dissatisfiers and defined as "dissatisfactionindicating reviews." The reason why "excellent" and "terrible" categories were selected in this study was to identify the most satisfied and the most dissatisfied customers and place them on a continuum of level of satisfaction. Comments in the "very good" category (the second highest level of five) and the "poor" category (the second lowest level) were excluded because even though these two groups of customers evaluated their experiences positively (or negatively), they still posted content of negative (or positive) aspects in a positive (or negative) review category. Therefore, in order to enhance the reliability of the interpretation of customer evaluation statements, this study attempted to examine the two extremes of evaluation, that is, the most highly satisfied "excellent" category and the most dissatisfied "terrible" category.

Second, hotels were classified into different levels, full-service and limited-service properties, according to diverse criteria, such as type of service, service level, quality of facilities, atmosphere, and rates (Ingram and Roberts, 2000; Jeong and Jeon, 2008). However, Trip Advisor only categorizes hotel class according to its own five-star rating system. The 
criteria of hotel star rating formulated by Trip Advisor are decided based on assessment sources provided by third-party partners, such as national ratings organizations and Expedia (Trip Advisor, 2015).

On the basis of Trip Advisor's star rating, a list of New York hotels was obtained in order to select full-service and limited-service hotels. One-star and two-star hotels were segmented as a limited-service hotel group, and four-star and five-star hotels were classified as a full-service hotel group. Three-star hotels were ruled out because the objective of this study was to compare high and low levels of customer expectation by identifying two hotel classes. Three-star hotels are not clearly distinguished as either full-service or limited-service. To select an equal number of full-service and limited-service hotels, the 50 top ranking hotels and the 50 bottom ranking hotels in Trip Advisor's New York list were selected. To guarantee valid data collection, a random sampling method was employed. Five positive and five negative comments posted about each hotel as of May 2013 were randomly chosen and recorded.

After collecting all of the available reviews, 250 satisfied and 221 dissatisfied for fullservice hotels, and 226 satisfied and 222 dissatisfied for limited-service hotels were singled out. As a consequence, a sample of 919 reviews out of 1,000 were employed for further analysis, because it was not always possible as there were often too few negative comments in the fullservice hotel reviews and not enough positive or negative comments in the limited-service hotel reviews. Table II presents the profiles of the selected hotels.

\section{Table II}




\section{Data analysis}

A content analysis method was applied to data analysis in order to develop clusters by analyzing text content (March and White, 2006). This method, validated by recent hospitality studies (Levy et al., 2013; Li et al., 2013), was used to identify particular factors in the large sample of information generated by customers on the Internet. There are several methodological approaches to analyzing content (Matthes and Kohring, 2008). Among them, this study adopted a manual holistic approach. It was found that some satisfaction-indicating reviews included negative experiences even though customers evaluated their hotel stay as "excellent", the highest level of satisfaction. A computer analytical program cannot discern the subtle differences in the meaning of words and can only count the frequency of keywords (Matthes and Kohring, 2008). Thus, it was decided not to employ a computer-aided program, but an in-depth manual review method.

This study followed the procedures of a manual holistic approach to content analysis (Marsh and White, 2006). First, to establish a coding table, a comprehensive list of hotel attributes and a typology of dissatisfiers were adopted from previous literature (Dolnicar and Otter, 2003; Levy et al., 2013). The coding list was helpful in establishing relevant and valid categories for data coding (Marsh and White, 2006; Matthes and Kohring, 2008). Second, in order to enhance validity of data analysis, each of the 50 final-year students majoring in hospitality in university in Hong Kong was assigned to review one of the 50 full-service and one of the 50 limited-service hotels on the New York hotel list. Then satisfiers for five satisfaction- 
indicating reviews and dissatisfiers for five dissatisfaction-indicating reviews, where they existed on one hotel's website on Trip Advisor, were initially coded by the students in an Excel file.

Third, based on the initially identified satisfiers and dissatisfiers in both full-service and limited-service hotels, the authors conducted in-depth analysis of both satisfaction- and dissatisfaction-indicating reviews by matching between satisfiers/dissatisfiers and the hotel attributes listed in the coding table developed by some studies (Dolnicar and Otter, 2003; Levy et al., 2013). These procedures to extract satisfiers and dissatisfiers were to improve reliability and to avoid subjectivity in assessment and analysis (Matthes and Kohring, 2008).

\section{Results}

The reviews of the 50 full-service hotels chosen numbered 42,659; those of the 50 limited-service hotels totaled 27,525. Of the reviews concerning the full-service hotels, 28,866 (67.7\%) were satisfaction-indicating reviews belonging to the "excellent" category, and 683 (1.6\%) were dissatisfaction-indicating ones in the "terrible" category. In contrast, analysis of the reviews of the 50 limited-service hotels showed a more balanced split of 4,374 dissatisfactionindicating reviews (15.8\%) and 3,920 satisfaction-indicating ones (14.2\%).

\subsection{Average of reviews showing hotel customer reactions}

Some reviewers who rated their overall experience as "excellent" also made negative comments. Within the full-service hotel segment, on average, 3.96 satisfaction-indicating reviews per hotel contained only satisfaction comments, whereas an average of 1.04 satisfactionindicating reviews per hotel included both satisfaction and negative comments, $79.2 \%$ and 
$20.8 \%$, respectively. Similarly, on average, 3.34 dissatisfaction-indicating reviews per hotel included only dissatisfaction comments, while an average of 1.08 dissatisfaction-indicating reviews per hotel contained both dissatisfaction and positive comments, $75.6 \%$ and $24.4 \%$, respectively.

In the limited-service hotel cohort, an average of 2.98 satisfaction-indicating reviews per hotel contained only satisfaction comments, whereas an average of 1.54 satisfaction-indicating reviews per hotel included both satisfaction and negative comments, nearly $66 \%$ and $34.1 \%$, respectively. An average of 3.06 dissatisfaction-indicating reviews per hotel in the limitedservice hotel segment included only dissatisfaction comments. However, an average of 1.38 dissatisfaction-indicating reviews per hotel included both dissatisfaction and positive comments, about $69 \%$ and $31.1 \%$, respectively. Figure I presents the average customer reactions.

\section{Figure I}

\subsection{Satisfiers and dissatisfiers in full-service and limited-service hotels}

The satisfiers and dissatisfiers were investigated across five hotel components: room, staff, hotel property/appearance, facility, and other. This five-part classification of hotel components is a modified version of the classification used in previous studies (Dolnicar and Otter, 2003; Levy et al., 2013). First of all, the satisfier structure found in this study encompassed 35 items in the room component, nine in the staff component, ten in the hotel 
property/appearance component, six in the facility component, and 32 in other component. The dissatisfier structure contained 36 items in the room component, ten in the staff component, eight in the hotel property/appearance component, seven in the facility component, and 35 in other component. The results of comparison of the 10 most highly ranked satisfiers and dissatisfiers between full-service and limited-service hotels are summarized in Table III.

The overall frequencies of the satisfiers and dissatisfiers in both hotel segments identified were 3,020 and 1,895, respectively. That is, a total of 85 satisfiers in full-service hotels and 75 in limited-service hotels were commented on 1,639 and 1,381 times, respectively. Ninety dissatisfiers in full-service hotels and 80 in limited-service hotels were discovered 850 and 1,045 times, respectively. Ultimately, 85 satisfiers and 90 dissatisfiers were discovered in the fullservice hotel segment and 75 satisfiers and 80 dissatisfiers in the limited-service hotel segment. The nine most frequent satisfiers and dissatisfiers extracted from the reviews of full-service and limited-service hotels are shown in Table III.

\section{Table III}

In full-service hotels, the most frequently found satisfiers were "location" (8.5\%), followed by "staff and their attitude" (8.3\%), "room size" (4.9\%), "service" (3.9\%), "breakfast" (3.8\%), "overall room" (3.5\%), "bed" (3.1\%), "view" (3.0\%), "neighborhood" (2.8\%), and "hotel style/design" (2.8\%). Regarding dissatisfiers in full-service hotels, "staff and staff 
attitude" (9.2\%) was the most mentioned, followed by "dirtiness" (5.9\%), "service" (3.7\%), "noisiness" (3.5\%), "management" (3.1\%), "manager attitude" (2.7\%), "room service" (2.7\%), "housekeeping service" (2.6\%), "restaurant" (2.5\%), and "bathroom" (2.5\%). Results of comparing the satisfiers and dissatisfiers in full-service hotels indicated that both were distinctively revealed, except for "staff and their attitude" and "service" pertaining to the staff component.

Results of comparing satisfiers and dissatisfiers in limited-service hotels differed from those in full-service hotels. The findings are presented in Table III. "Location" was the most significant satisfier $(10.8 \%)$ in the limited-service hotel segment, followed by "staff and their attitude" (9.7\%), "room cleanliness" (7.6\%), "transportation" (5.9\%), "neighborhood" (5.5\%), "room rate" (4.9\%), "bed" (4.1\%), "bathroom" (4.1\%), "breakfast" (3.3\%), and "room size” (3.2\%). "Dirtiness" was ranked as the most significant dissatisfier $(8.2 \%)$ in the limited-service hotel segment, followed by "staff and staff attitude" (6.6\%), "room size" (6.3\%), "noisiness" (5.9\%), "bathroom" (4.9\%), "bed" (3.1\%), "temperature" $(2.4 \%)$, "old building" $(2.4 \%)$, "front desk staff" (2.3\%), "smell” (2.3\%), and "value for money" (2.3\%). Six factors, "staff and their attitude," "room cleanliness/dirtiness," "bed," "bathroom," "room size," and "room rate/value for money," were found among both satisfiers and dissatisfiers in limited-service hotels.

\subsection{Satisfiers in full-service and limited-service hotels}

The highest ranked satisfiers that indicate top nine satisfiers in full-service and limitedservice hotels were compared, as shown in Table III. Among ten satisfiers compared in each segment, six were common to both hotel segments: "location," "staff and their attitude," "room 
size," "breakfast," "bed," and "neighborhood." Interestingly, "location" and "staff and their attitude" were very significant in both full-service and limited-service hotels. However, apart from the six common items, satisfiers differed between the two hotel cohorts. That is, the satisfiers identified only in full-service hotels were "service," "overall room," "view from room," and "hotel style and design"; the satisfiers identified only in limited-service hotels were "room cleanliness," "transportation," "room rate," and "bathroom."

\subsection{Dissatisfiers in full-service and limited-service hotels}

As above, the highest ranked top nine dissatisfiers in the full-service and limited-service hotel segments were compared, as also illustrated in Table III. Among ten dissatisfiers in fullservice hotels and eleven in limited-service hotels, four were common to both segments: "staff and their attitude," "dirtiness," "noisiness," and "bathroom." In addition, "staff and their attitude" and "dirtiness" were noted as the two most salient dissatisfiers in both hotel segments. Beside the four common items, dissatisfiers in full-service and limited-service hotels differed. The dissatisfiers identified only in full-service hotels were "service," "management," "manager attitude," "room service," "housekeeping staff," and "restaurant"; those discovered only in limited-service hotels were "room size" "bed," "room temperature," "old building," "front desk staff," "smell," and "value for money." These results are also reported in Table III and illustrated in Figure II.

\section{Figure II}




\subsection{Average number of satisfiers and dissatisfiers in each review}

Further analysis was conducted to understand how many satisfiers or dissatisfiers are contained in an average satisfaction-indicating or dissatisfaction-indicating review. The findings are reported in Figure III. Within the full-service hotel segment, satisfiers were mentioned 1,639 times in 250 satisfaction-indicating reviews and dissatisfiers were mentioned 850 times in 221 dissatisfaction-indicating reviews. Within the limited-service hotel cohort, satisfiers were mentioned 1,381 times in 226 satisfaction-indicating reviews, while dissatisfiers were mentioned 1,044 times in 222 dissatisfaction-indicating reviews.

Within the full-service hotel segment, therefore, an average of 6.6 satisfiers were identified per satisfaction-indicating review and an average of 3.8 dissatisfiers were found in each dissatisfaction-indicating review. Within the limited-service hotel segment, on average, satisfaction-indicating reviews had 6.1 satisfiers and dissatisfaction-indicating reviews 4.7 dissatisfiers.

\section{Figure III}




\section{Conclusion and discussion}

Significant findings based on the analysis of various satisfiers and dissatisfiers in this study are as follows. First, analysis of 42,659 reviews in the full-service hotel segment and 27,525 reviews in the limited-service hotel segment indicates that full-service hotel customers tend to participate more actively than limited-service hotel customers in commenting on their stay experience via online review channels. Full-service hotels had noticeably more satisfactionindicating reviews $(67.7 \%)$ than dissatisfaction-indicating reviews $(1.6 \%)$. This result is consistent with those of previous studies, which find that positive reviews generally outnumber negative ones (Li et al., 2013; Pantelidis, 2010).

In contrast, it was discovered that in the limited-service hotel cohort, dissatisfactionindicating reviews (15.8\%) only slightly outnumbered satisfaction-indicating reviews (14.2\%). This finding contradicts that of Li and colleagues (2013), who found that satisfaction-indicating reviews far outnumbered dissatisfaction-indicating ones. In fact, since limited-service hotel customers tend to pay less for their hotel stay, the operational strategy of managing a limitedservice hotel is to provide a minimal level of services and facilities (Forbes Travel Guide, 2015; Jeong and Jeon, 2008; Justus, 1991). However, since customers still require a certain level of facilities and services in a limited-service hotel (Griffin et al., 1997; Knutson, 1988; Knutson et al., 1993; Li et al., 2013; Nasution and Mavondo, 2008), there is a need to proactively improve low-cost hotel services and facilities. For example, limited-service hotel management needs to recognize the importance of social media as a cost-effective method of improvement, and constantly monitor the reasons for customer dissatisfaction through customer-generated online hotel review systems. 
Second, it was discovered that $20.8 \%$ of satisfied customers in the full-service hotel segment and $34.1 \%$ of satisfied customers in the limited-service hotel cohort included unfavorable comments in satisfaction-indicating reviews. About $24.4 \%$ of unsatisfied customers in the full-service hotel cohort and $31.1 \%$ of unsatisfied customers in the limited-service hotel segment also made favorable comments in dissatisfaction-indicating reviews. It means that negative comments in satisfaction-indicating reviews and positive comments in dissatisfactionindicating reviews coexist. The pattern of mixed positive and negative comments is similar to previous studies indicating a "neutral factor" that does not elicit salient effects on satisfaction and dissatisfaction (Cadotte and Turgeon, 1988). In other words, this finding implies that it is unrealistic for a hotel to provide perfect services because each customer has his/her own individual utility, purpose of stay, and perception of quality of experience (Fisk et al., 1993). However, it is believed that coexistence of salient satisfiers and dissatisfiers leads to satisfaction and/or dissatisfaction. Therefore, there is a need for hotel marketers and researchers to analyze thoroughly both the satisfiers and dissatisfiers that customers perceive as a result of their experience.

Third, according to the identification of ranks and items of both satisfiers and dissatisfiers in both full-service and limited-service hotels, satisfiers in the full-service hotel segment were germane to the room and other components, while dissatisfiers were mainly pertinent to the service component. On the other hand, satisfiers in the limited-service hotel cohort were focused in the other and room components, and dissatisfiers in the room component. As a result, these findings do not show a consensus comparable to those of earlier studies that applied Herzberg's 
two-factor theory that satisfiers indicate intangible features and dissatisfiers tangible features (Chan and Baum, 2007; Herzberg et al., 1958; Herzberg, 1966; Jones et al., 1997).

The results of this study show that most satisfiers in the full-service hotel segment were associated with tangible features, while most dissatisfiers showcased a tendency of demonstrating intangible features. Interestingly, in the limited-service hotels, most satisfiers and dissatisfiers manifested tangible characteristics. It shows that only the pattern of dissatisfiers in the limited-service hotel segment was consistent with Herzberg's two-factor theory. The result is also supported by previous studies that examined hotel customers' satisfiers and dissatisfiers (Chan and Baum, 2007; Johns and Howard, 1998; Jones et al., 1997). Previous studies put emphasis on the importance of customer expectation, indicating that it plays a significant role in satisfaction and dissatisfaction (Anderson and Sullivan, 1993; Dolnicar, 2002; Oliver, 1980; Oliver and Linda, 1981). This study is meaningful in that it has empirically proven that customers' satisfiers and dissatisfiers can differ according to their expectation level.

Fourth, "staff and their attitude" and "service" were highly ranked among both satisfiers and dissatisfiers within the full-service hotel segment. They were highly related to the staff component, including intangible features as service-related factors which are essential not only to pleasing customers but also to ruining their experiences. According to the hotel rating system (Forbes Travel Guide, 2015), an full-service hotel is required to provide personalized high-end services as well as luxurious facilities to deliver a remarkable level of service performance. The results mean that full-service hotel customers consider human-related factors to be very important for satisfactory experiences in full-service hotels (Walls et al., 2011). Similar to fullservice hotels, "staff and their attitude" was listed as the second most important satisfier and 
dissatisfier in limited-service hotels. However, "service" was found to be neither a satisfier nor a dissatisfier in limited-service hotels. This means that even though "staff and their attitude" was perceived as important in the limited-service hotel segment, "service" is not a crucial factor. This is understandable because a limited-service hotel strategically offers basic and essential facilities as well as acceptable service to cater to the needs of economizing customers (Fiorentino, 1995; Forbes Travel Guide, 2015).

Fifth, investigating the satisfiers and dissatisfiers in limited-service hotels generated six common factors: "staff and their attitude," "room cleanliness/dirtiness," "bed," "bathroom," "room size," and "room rate/value for money." "Room cleanliness/dirtiness," "bed," "bathroom," and "room size" were closely related to the room component, which customers consider fundamental to their hotel stay. This is consistent with the findings of previous studies showing that complaint issues related to both staff and room features are more frequent in bottom-ranking hotels than top-ranking hotels (Lee and Hu, 2004; Levy et al., 2013; Sparks and Bradley, 2014; Sparks and Browning, 2011).

Among the six common factors, "room size" was ranked far more higher as a dissatisfier than a satisfier in the limited-service hotels. However, it was regarded as the only high-ranking satisfier in the full-service hotels. This implies that "room size" is very satisfying in full-service hotels in New York City, and very unsatisfying in limited-service hotels. This is understandable because limited-service hotel management is not able to provide more spacious rooms than fullservice hotels because of the high room rates in New York City (Gladstone and Fainstein, 2001). In addition, price-related factors such as "room rate" and "value for money" were commonly identified as both satisfier and dissatisfier in the limited-service hotel segment. This implies that 
limited-service hotel customers' main concern is a reasonable room rate (Fiorentino, 1995; Justus, 1991). In other words, a limited-service hotel customer shows high sensitivity to room conditions despite paying a low rate (Dolnicar, 2002).

As a consequence, service-related factors in full-service hotels and room-related factors in limited-service hotels were identified as important to both customer satisfaction and dissatisfaction. Interestingly, it can be concluded that the most significant factor in a hotel, regardless of customers' level of satisfaction and expectation, is "staff and their attitude." As a result, staff's job performance capacity and their attitude in full-service hotels, and room conditions in limited-service hotels, should be enhanced. Different strategies to alleviate customer dissatisfaction need to be adopted in full-service and limited-service hotels.

Sixth, six salient satisfiers identified in both full-service and limited-service hotels were "location," "staff and their attitude," "room size," "breakfast," "bed," and "neighborhood." Among these, "location" and "staff and their attitude" were the most highly ranked. This reflects conventional wisdom that convenient location and courteous staff attitude help to enhance customer satisfaction (Jeong and Jeon, 2008; Knutson, 1988; Li et al., 2013).

Seventh, noticeable dissatisfiers in both hotel segments included "staff and their attitude," "dirtiness," "noisiness," and "bathroom." Specially, "staff and their attitude" and "dirtiness" were the most highly ranked dissatisfiers. This result agrees with that of Levy and colleagues (2013). In addition, dissatisfiers in full-service hotels were more likely to be related to the staff component, while those of limited-service hotels were related to the room component. This is consistent with the requirement of standards reflected in the hotel rating system. That is, fullservice hotels should provide the finest facilities and excellent services that exceed customers' 
expectations. On the other hand, limited-service hotels should provide at least a minimal, tolerable level of service and facilities in order to meet limited-service hotel customers' expectations (Cadotte and Turgeon, 1988; Costa et al., 2004; Forbes Travel Guide, 2015; Jeong and Jeon, 2008). Limited-service hotel management generally emphasizes management strategies to provide customers with convenience and low prices. However, the results of this study imply that they should not neglect to provide a certain level of service and facilities, and they should understand precisely and eliminate the causes of the dissatisfiers discovered in this study.

\section{Theoretical implications}

By analyzing customer-generated online hotel reviews in terms of whether they indicate satisfaction or dissatisfaction with full- and limited-service hotels, this study contributes to the advancement of theoretical knowledge by answering the research questions. This study takes a bi-dimensional approach, based on Herzberg's two-factor theory, to online hotel reviews to develop a factor structure for both satisfiers and dissatisfiers. The two-factor theory has been adopted and extended in the hospitality literature to identify satisfiers and dissatisfiers by focusing on their distinctive intangible or tangible characteristics (Cadotte and Turgeon, 1988; Chan and Baum, 2007; Johns and Howard, 1998; Jones et al., 1997). This study explores the factor structure in the extended version of Herzberg's two-factor theory by considering the importance of hotel class. This is predicated on the belief that that a full-service hotel will generate a high level of customer expectations, whereas a limited-service hotel will be linked to a 
lower level of expectations. The study identifies the satisfiers and dissatisfiers generated by online hotel customers and assess the impact of hotel class.

The findings partially support the hypotheses of Herzberg's two-factor theory in terms of the coexistence of both satisfiers and dissatisfiers for hotels. Moreover, the factor structures determining satisfaction and dissatisfaction were affected by hotel class. This shows the extent to which satisfiers and dissatisfiers, respectively, are important, and which services and facilities can enable an improvement in satisfaction while alleviating dissatisfaction. In addition, management in hotels of different classes should pay attention to their customers' specific needs and wants, as represented by particular satisfiers, and the possible sources of complaints with reference to dissatisfiers.

In particular, the most critical factor in both satisfaction and dissatisfaction across all hotel classes was "staff and staff attitude." This findings shows that staff are the key contributor to customer evaluation, and awareness of this is essential in understanding their significant role in hospitality and hotel management research. Since staff development is rarely standardized effectively, hotel management should offer their staff appropriate training, standardized service manuals, and reasonable compensation to encourage them to improve customer satisfaction and prevent dissatisfaction (Yim et al., 2008).

\section{Practical implications}

Hotel management must also realize satisfaction and dissatisfaction, respectively, from the customer perspective. A successful business results not only from generating satisfaction, but also by simultaneously avoiding dissatisfaction. As social media now permeates most people's 
lives, recognizing its significance in the era of advanced technology is essential. It has an important role in hotel management development because it allows free access and interactive communication between customers and hotel practitioners (Gretzel and Yoo, 2008; McCarthy et al., 2010). Unlike traditional feedback forms, such as thank you letters and complaint cards, social media permits easy and instant scrutiny of customers' reactions (McCarthy et al., 2010; Sparks and Browning, 2011; Verma et al., 2012; Vermeulen and Seegers, 2009). From the perspective of cost-effectiveness, the use of social media tools is one of the best means of enhancing service quality and facility improvement since it avoids the additional marketing costs of traditional methods used to obtain and understand customer assessment (Law et al., 2014). Therefore, hotel management is required to proactively utilize cyber space and the content on social media as communication and monitoring tools.

The findings of this study imply that the way in which social media is used should differ between full-service and limited-service hotels. Full-service hotels should use positive customers' evaluations as a reliable and trustworthy promotion tool, and profit from the critical aspects of negative comments in order to facilitate a zero-defect service. Limited-service hotels are recommended to make efficient use of social media platforms to promote their hotel brand and their specialized services and facilities. For example, limited-service hotels need to monitor satisfied customers as evaluators who voluntarily participate in sharing their experience by commenting and spreading positive word-of-mouth.

In conclusion, this study validates Herzberg's two-factor theory, which indicates the existence of distinct satisfiers and dissatisfiers. In addition, the findings relating to different satisfiers and dissatisfiers in two hotel classes imply that managerial strategies differ according 
to hotel class. Service and staff attitude are significant factors for full-service hotel customers, while staff and room-related factors are significant elements for limited-service hotel customers. As a result, this study recommends that staff and their attitude is the most significant factor in (dis)satisfying customers regardless of hotel class.

\section{Limitations and future research}

There are some limitations to this study. First, it employed reviews of New York City hotels posted on Trip Advisor, but results can vary depending on hotels' regional location. Second, in this study satisfied comments were only selected from the "excellent" category for satisfaction-indicating reviews, while dissatisfied comments were selected only from the "terrible" category for dissatisfaction-indicating reviews. Future study may explore a wider range of comments in order to provide a more detailed analysis of customer evaluation. Third, future research is required to compare the findings of this study with those obtained using a computeraided program. Fourth, the online hotel reviews analyzed in this study reflected only the customers' reactions. However, Trip Advisor provides several additional data, such as customers' demographic information. Thus, future study should explore how findings can differ according to customer's demographic profile. Fifth, negative comments in satisfaction-indicating reviews and positive comments in dissatisfaction-indicating reviews were not included for analysis in this study. A future study needs to assess these comments. Sixth, this study analyzed the five most recent positive and negative reviews due to time restrictions. The time range of the comments should be extended. Future research needs to explore the hotel practitioners' perspective and how hotels attempt to implement service recovery strategies in response to customers' negative comments after analyzing online reviews. 
Table I. Satisfiers and dissatisfiers in the hotel context

\begin{tabular}{|c|c|c|}
\hline \multirow{6}{*}{ Satisfiers } & $\begin{array}{l}\text { Barsky and Labagh } \\
\text { (1992), } \\
\text { Barsky (1992) } \\
\text { Business and Leisure } \\
\text { traveler }\end{array}$ & $\begin{array}{l}\text { Employee attitudes, location, room, price, facilities, reception, services, } \\
\text { parking, F\&B }\end{array}$ \\
\hline & $\begin{array}{l}\text { Gunderson, Heide, } \\
\text { and Olsson (1996) } \\
\text { Business traveler }\end{array}$ & $\begin{array}{l}\text { Receptionist's willingness to provide service, receptionist's ability to } \\
\text { provide service, receptionist's ability to provide quick service, } \\
\text { receptionist's accuracy in registration, F\&B personnel's willingness to } \\
\text { provide service, F\&B personnel's ability to provide service, opening } \\
\text { hours of the F\&B department, housekeeping personnel's willingness to } \\
\text { provide service, housekeeping personnel's ability to provide service, } \\
\text { amenities in the hotel room, comfort of the hotel room, availability of } \\
\text { room during stay }\end{array}$ \\
\hline & $\begin{array}{l}\text { Choi and Chu (2000, } \\
\text { 2001) } \\
\text { Asian, Western traveler }\end{array}$ & $\begin{array}{l}\text { Staff service, room quality, general amenities, business services, value, } \\
\text { security, international direct dial facility }\end{array}$ \\
\hline & $\begin{array}{l}\text { Qu, Ryan, and Chu } \\
\text { (2000) } \\
\text { International traveler }\end{array}$ & $\begin{array}{l}\text { Quality of staff performance, quality of room facilities, value for } \\
\text { money, variety \& efficiency of service, business-related services, safety } \\
\text { \& security }\end{array}$ \\
\hline & $\begin{array}{l}\text { Poon and Low (2005) } \\
\text { Asian, Western traveler }\end{array}$ & $\begin{array}{l}\text { Hospitality, accommodation, F\&B, recreation \& entertainment, } \\
\text { supplementary service, security \& safety, innovation \& value added } \\
\text { services, transportation, location, appearance, pricing, payment }\end{array}$ \\
\hline & $\begin{array}{l}\text { Gu and Ryan (2008) } \\
\text { Chinese traveler }\end{array}$ & $\begin{array}{l}\text { Bed comfort, bathroom cleanliness and facilities, room size and } \\
\text { facilities, location and accessibility, staff performance, ancillary } \\
\text { services (pool, beauty salon, etc.), food and drink }\end{array}$ \\
\hline \multirow[t]{2}{*}{ Dissatisfiers } & $\begin{array}{l}\text { Heung }(\mathbf{2 0 0 0}) \\
\text { Mainland Chinese } \\
\text { traveler }\end{array}$ & $\begin{array}{l}\text { Recreational facilities, frequent traveler programs, baggage handling } \\
\text { services, complimentary amenities, pool and gym facilities, physical } \\
\text { appearance, view of surrounding area, transportation arrangements, } \\
\text { business center, meeting facilities, hotel reputation, reasonable prices, } \\
\text { fire prevention systems, reservation system, security, efficiency of front } \\
\text { desk, laundry service, value for money of F\&B, hotel staff, promptness } \\
\text { of service }\end{array}$ \\
\hline & $\begin{array}{l}\text { Dolnicar (2002) } \\
\text { Business traveler }\end{array}$ & $\begin{array}{l}\text { Weakness of cleanliness, room, personnel, service, food, bed, technical } \\
\text { equipment bathroom; unfriendly staff, noisy atmosphere, room size, } \\
\text { excessive pricing, bad location, low quality }\end{array}$ \\
\hline
\end{tabular}


Table II. Profiles of selected hotels

\begin{tabular}{cccc}
\hline Segment & Hotel class & Total & Selected \\
\hline $\begin{array}{c}\text { Full-service Hotel } \\
(N=50)\end{array}$ & 5 star & 28 & 28 \\
\cline { 2 - 4 } & 4 star & 120 & 22 \\
\hline $\begin{array}{c}\text { Limited-service Hotel } \\
(N=50)\end{array}$ & 2 star & 112 & 0 \\
\cline { 2 - 4 } & 1 star & 45 & 41 \\
\hline & All & 9 & 9 \\
\hline
\end{tabular}

Note: 3-star hotels were excluded because they are located between full-service and limited-service hotel segments. 
Table III. Comparison of satisfiers and dissatisfiers between full-service and limited-service hotels

\begin{tabular}{|c|c|c|c|c|c|c|c|c|c|}
\hline \multicolumn{10}{|c|}{ Full-service hotel $(N=50)$} \\
\hline Rank & Satisfiers & $\begin{array}{c}\text { Hotel } \\
\text { Components }\end{array}$ & Frequency & Percentage & Rank & Dissatisfiers & $\begin{array}{c}\text { Hotel } \\
\text { Components }\end{array}$ & Frequency & Percentage \\
\hline 1 & Location & $\mathrm{O}$ & 139 & 8.5 & 1 & Staff and their attitude & $\mathrm{S}$ & 78 & 9.2 \\
\hline 2 & Staff and their attitude & $\mathrm{S}$ & 136 & 8.3 & 2 & Dirtiness & $\mathrm{R}$ & 50 & 5.9 \\
\hline 3 & Room size & $\mathrm{R}$ & 80 & 4.9 & 3 & Service & $\mathrm{S}$ & 32 & 3.7 \\
\hline 4 & Service & $\mathrm{S}$ & 64 & 3.9 & 4 & Noisiness & $\mathrm{R}$ & 30 & 3.5 \\
\hline 5 & Breakfast & $\mathrm{O}$ & 62 & 3.8 & 5 & Management & $\mathrm{O}$ & 26 & 3.1 \\
\hline 6 & Room & $\mathrm{R}$ & 57 & 3.5 & 6 & Manager attitude & $\mathrm{S}$ & 23 & 2.7 \\
\hline 7 & Bed & $\mathrm{R}$ & 50 & 3.1 & 6 & Room service & $\mathrm{S}$ & 23 & 2.7 \\
\hline 8 & View & $\mathrm{R}$ & 49 & 3.0 & 8 & Housekeeping service & $\mathrm{S}$ & 22 & 2.6 \\
\hline 9 & Neighborhood & $\mathrm{O}$ & 46 & 2.8 & 9 & Restaurant & $\mathrm{O}$ & 21 & 2.5 \\
\hline 9 & Hotel style/design & $\mathrm{H}$ & 46 & 2.8 & 9 & Bathroom & $\mathrm{R}$ & 21 & 2.5 \\
\hline Total & 85 & $\begin{array}{l}\mathrm{R}: 4, \mathrm{~S}: 2 \\
\mathrm{H}: 1, \mathrm{O}: 3\end{array}$ & 1,639 & & Total & 90 & $\begin{array}{l}\mathrm{R}: 3, \mathrm{~S}: 5 \\
\mathrm{O}: 2\end{array}$ & 850 & \\
\hline \multicolumn{10}{|c|}{ Limited-service hotel $(N=50)$} \\
\hline Rank & Satisfiers & $\begin{array}{c}\text { Hotel } \\
\text { Components }\end{array}$ & Frequency & Percentage & Rank & Dissatisfiers & $\begin{array}{c}\text { Hotel } \\
\text { Components }\end{array}$ & Frequency & Percentage \\
\hline 1 & Location & $\mathrm{O}$ & 149 & 10.8 & 1 & Dirtiness & $\mathrm{R}$ & 86 & 8.2 \\
\hline 2 & Staff and their attitude & $\mathrm{S}$ & 134 & 9.7 & 2 & Staff and their attitude & $\mathrm{S}$ & 69 & 6.6 \\
\hline 3 & Room cleanliness & $\mathrm{R}$ & 105 & 7.6 & 3 & Room size & $\mathrm{R}$ & 66 & 6.3 \\
\hline 4 & Transportation & $\mathrm{O}$ & 82 & 5.9 & 4 & Noisiness & $\mathrm{R}$ & 62 & 5.9 \\
\hline 5 & Neighborhood & $\mathrm{O}$ & 76 & 5.5 & 5 & Bathroom & $\mathrm{R}$ & 51 & 4.9 \\
\hline 6 & Room rate & $\mathrm{O}$ & 68 & 4.9 & 6 & Bed & $\mathrm{R}$ & 32 & 3.1 \\
\hline 6 & Bed & $\mathrm{R}$ & 57 & 4.1 & 7 & Temperature & $\mathrm{R}$ & 25 & 2.4 \\
\hline 8 & Bathroom & $\mathrm{R}$ & 56 & 4.1 & 7 & Old building & $\mathrm{H}$ & 25 & 2.4 \\
\hline 9 & Breakfast & $\mathrm{O}$ & 45 & 3.3 & 9 & $\begin{array}{l}\text { Front desk staff and their } \\
\text { service }\end{array}$ & $\mathrm{S}$ & 24 & 2.3 \\
\hline 10 & Room size & $\mathrm{R}$ & 44 & 3.2 & 9 & Smell & $\mathrm{R}$ & 24 & 2.3 \\
\hline & & & & & 9 & Value for money & $\mathrm{O}$ & 24 & 2.3 \\
\hline Total & 75 & $\begin{array}{l}\mathrm{R}: 4, \mathrm{~S}: 1 \\
\quad \mathrm{O}: 5\end{array}$ & 1,381 & & Total & 80 & $\begin{array}{l}\text { R: 7, S: } 2 \\
\text { H: } 1, \mathrm{O}: 1\end{array}$ & 1,045 & \\
\hline
\end{tabular}

Note: Five hotel components (R: Room, S: Staff, H: Hotel property/appearance, F: Facility, O: Other component) 
Figure I. Average of reviews showing hotel customer reactions

Full-service hotels

3.96

\section{$(79.2 \%)$}

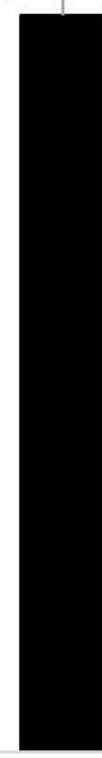

Only satisfactory comments included comments and negative comment

Satisfaction-indicating reviews $(N=250)$

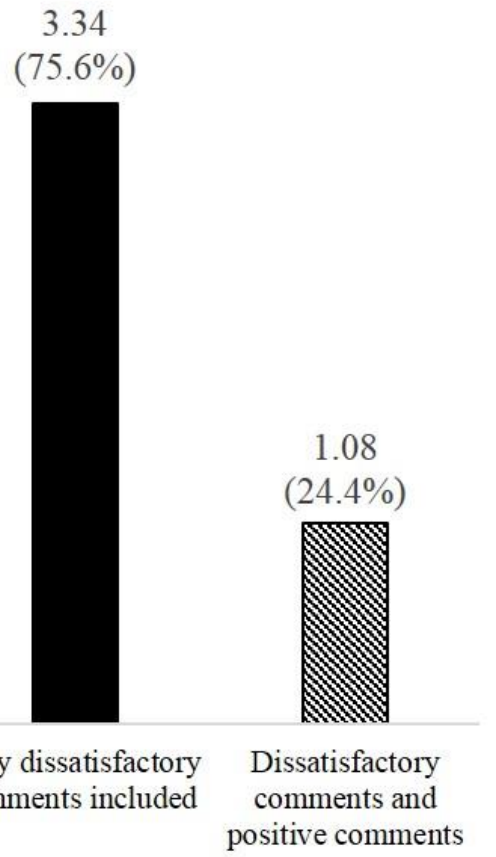

Dissatisfaction-indicating reviews $(N=221)$
Limited-service hotels
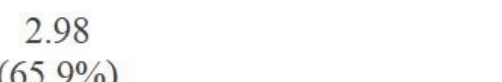

$(68.9 \%)$
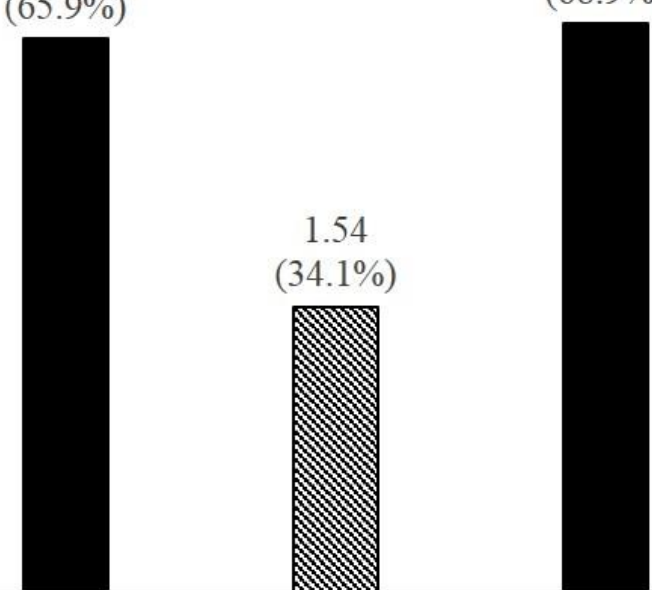

1.38

$(31.1 \%)$
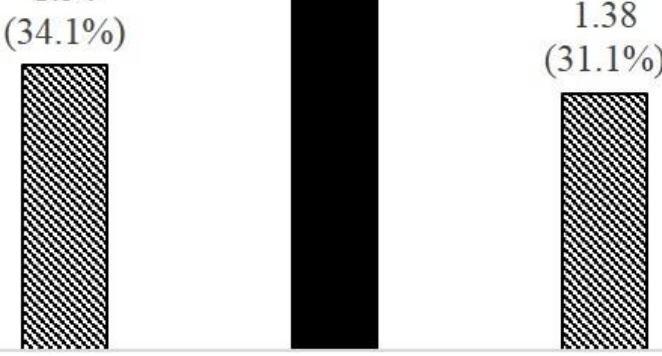

Only satisfactory

satisfactory

Only dissatisfactory Dissatisfactory comments included comments and comments included comments \& positive comments

Satisfaction-indicating reviews $(N=226)$

Dissatisfaction-indicating review $(N=222)$ 
Figure II. Comprehensive structure of satisfiers and dissatisfiers in full-service and limited-service hotels

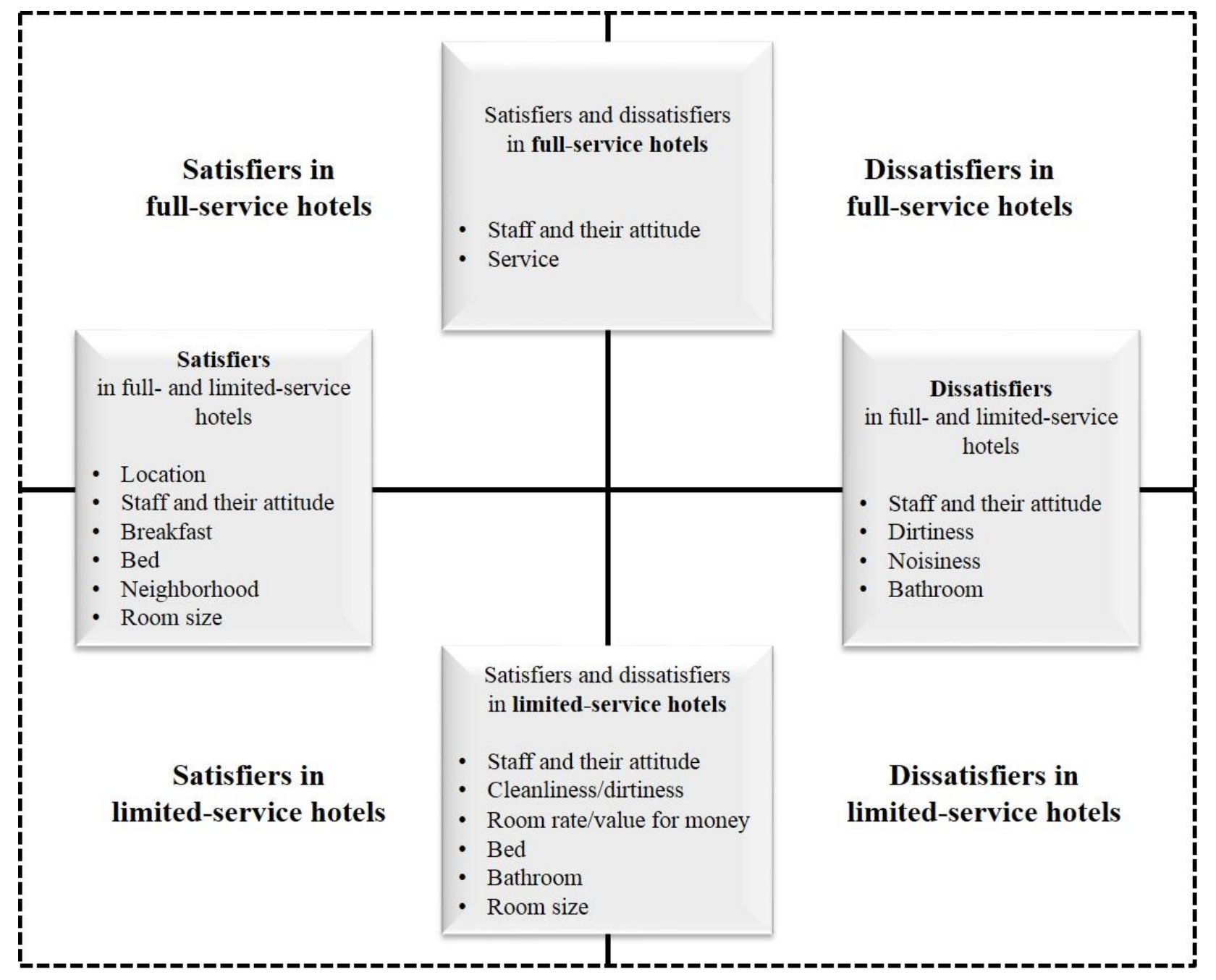


Figure III. Average number satisfiers and dissatisfiers in each review

Full-service hotels

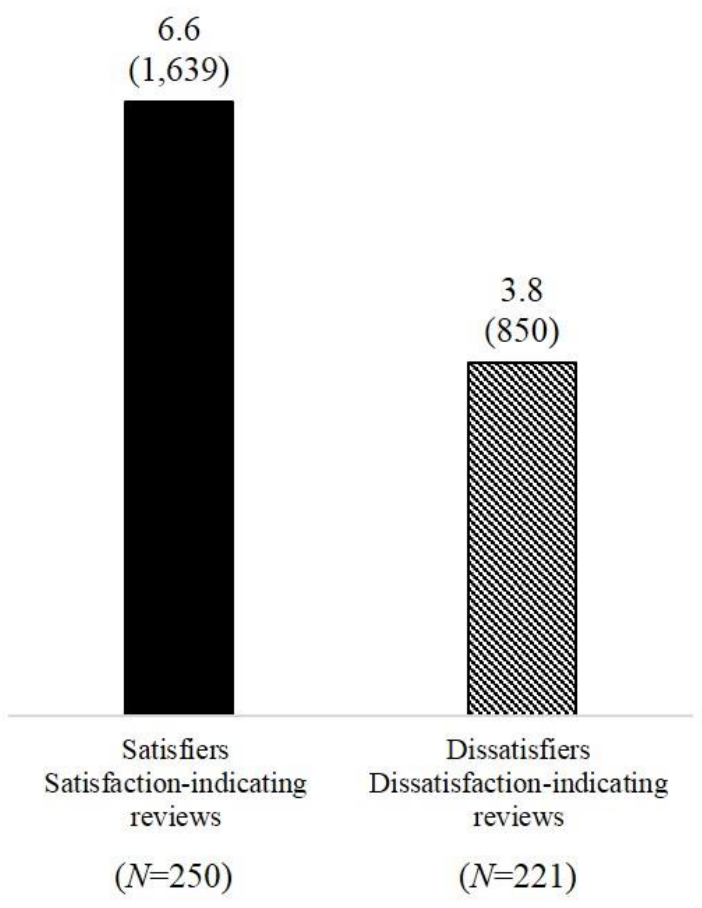

Limited-service hotels

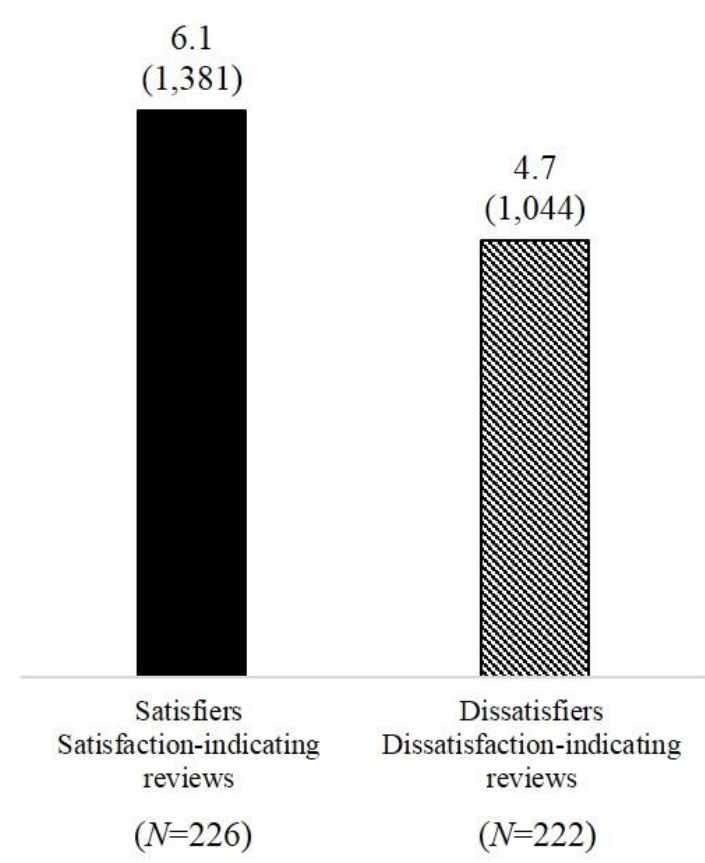

Note: Numbers in parentheses indicate total frequency of satisfiers or dissatisfiers. 


\section{References}

Alegre, J. and Garau, J. (2010), “Tourist Satisfaction and Dissatisfaction”, Annals of Tourism Research, Vol. 37 No. 1, pp. 52-73.

Anderson, E.W., Fornell, C. and Lehmann, D.R. (1994), “Customer satisfaction, market share, and profitability: Findings from Sweden", The Journal of Marketing, pp. 53-66.

Anderson, E.W. and Sullivan, M.W. (1993), "The antecedents and consequences of customer satisfaction for firms", Marketing science, Vol. 12 No. 2, pp. 125-143.

Babin, B.J. and Griffin, M. (1998), “The nature of satisfaction: an updated examination and Analysis", Journal of Business research, Vol, 41 No. 2, pp. 127-136.

Barsky, J.D. (1992), "Customer Satisfaction in the Hotel Industry Meaning and Measurement", Journal of Hospitality \& Tourism Research, Vol. 16 No. 1, pp. 51-73.

Barsky, J.D. and Labagh, J. (1992), “A strategy for customer satisfaction”, Cornell Hotel and Restaurant Administration Quarterly, Vol. 33 No. 5, pp. 32-40.

Berezina, K., Bilgihan, A., Cobanoglu, C. and Okumus, F. (2015), "Understanding Satisfied and Dissatisfied Hotel Customers: Text Mining of Online Hotel Reviews", Journal of Hospitality Marketing \& Management, (ahead-of-print), pp. 1-24.

Cadotte, E.R. and Turgeon, N. (1988), "Key factors in guest satisfaction”, Cornell Hotel and Restaurant Administration Quarterly, Vol. 28 No. 4, pp. 44-51.

Cardozo, R.N. (1965), “An experimental study of customer effort, expectation, and satisfaction”, Journal of marketing research, Vol. 2 No. 3, pp. 244-249.

Chan, J.K.L. and Baum, T. (2007), "Researching Consumer Satisfaction”, Journal of Travel \& Tourism Marketing, Vol. 23 No. 1, pp. 71-83.

Chan, N.L. and Guillet, B.D. (2011), "Investigation of social media marketing: how does the hotel industry in Hong Kong perform in marketing on social media websites?", Journal of Travel \& Tourism Marketing, Vol. 28 No. 4, pp. 345-368.

Choi, T.Y. and Chu, R. (2000), "Levels of satisfaction among Asian and Western travelers", International Journal of Quality \& Reliability Management, Vol. 17 No. 2, pp. 116-132.

Costa, G., Glinia, E., Goudas, M. and Antoniou, P. (2004), Recreational services in resort hotels: Customer satisfaction aspects", Journal of Sport \& Tourism, Vol. 9 No. 2, pp. 117-126.

Dolnicar, S. (2002), "Business travellers' hotel expectations and disappointments: A different perspective to hotel attribute importance investigation”, Asia Pacific Journal of Tourism Research, Vol. 7 No. 1, pp. 29-35.

Dolnicar, S. and Otter, T. (2003), "Which hotel attributes matter?", A review of previous and a framework for future research.

Fiorentino, A. (1995), "Budget hotels: not just minor hospitality products", Tourism Management, Vol. 16 No. 6, pp.455-462.

Fisk, R.P., Brown, S.W. and Bitner, M.J. (1993), "Tracking the evolution of the services 
marketing literature", Journal of Retailing Vol. 69 No. 1, pp. 61-103.

Forbes Travel Guide (2015), Forbes Travel Guide's Ratings: The Original Five Star Standard, Retrieved from http://www.forbestravelguide.com/about/ratings.

Gladstone, D.L. and Fainstein, S.S (2001), "Tourism in US global cities: A comparison of New York and Los Angeles", Journal of Urban Affairs, Vol. 23 No. 1, pp. 23-40.

Gretzel, U. and Yoo, K.H. (2008), "Use and impact of online travel reviews", Information and communication technologies in tourism, pp. 35-46.

Griffin, R.K., Shea, L. and Weaver, P. (1997), "How business travelers discriminate between mid-priced and luxury hotels: an analysis using a longitudinal sample", Journal of Hospitality \& Leisure Marketing, Vol. 4 No. 2, pp. 63-75.

$\mathrm{Gu}, \mathrm{H}$. and Ryan, C. (2008), "Place attachment, identity and community impacts of tourism-the case of a Beijing hutong", Tourism Management, Vol. 29 No. 4, pp. 637-647.

Harwood, S. (2007), "Travellers trust user reviews over travel agent content", Revolution UK.

Hennig-Thurau, T., Gwinner, K.P., Walsh, G. and Gremler, D.D. (2004), "Electronic word-ofmouth via consumer-opinion platforms: what motivates consumers to articulate themselves on the internet?", Journal of interactive marketing, Vol. 18 No. 1, pp. 38-52.

Herzberg, F. (1966), “Motivate Employees?” World, 88.

Herzberg, F. Mausner, B. and Snyderman, B.B. (1958), "The Motivation to Work”, Transaction Publishers, New Brunswick, New Jersey. Originally published in 1959 by John Wiley \& Sons, Inc.

Heung, V.C. (2000), "Satisfaction levels of mainland Chinese travelers with Hong Kong hotel Services", International Journal of Contemporary Hospitality Management, Vol. 12 No. 5, pp. 308-315.

Hoffman, K.D. and Chung, B.G. (1999), "Hospitality recovery strategies: Customer preference versus firm use", Journal of Hospitality \& Tourism Research, Vol. 23 No. 1, pp. 71-84.

Ingram, P. and Roberts, P.W. (2000), "Friendships among Competitors in the Sydney Hotel Industry", American journal of sociology, Vol. 106 No. 2, pp. 387-423.

Jeong, M. and Jeon, M.M. (2008), "Customer reviews of hotel experiences through consumer generated media (CGM)", Journal of Hospitality \& Leisure Marketing, Vol. 17 No. 1-2, pp. 121-138.

Jeong, M., Oh, H. and Gregoire, M. (2003), "Conceptualizing web site quality and its consequences in the lodging industry", International Journal of Hospitality Management, Vol. 22 No. 2, pp. 161-175.

Johns, N. and Howard, A. (1998), "Customer expectations versus perceptions of service performance in the foodservice industry", International Journal of Service Industry Management, Vol. 9 No. 3, pp. 248-265.

Johnston, R. (1995), "The determinants of service quality: satisfiers and dissatisfiers", International journal of service industry management, Vol. 6 No. 5, pp. 53-71. 
Jones, N., Lee-Ross, D. and Ingram, H. (1997), “A study of service quality in small hotels and Guesthouses", Progress in Tourism and Hospitality Research, Vol. 3 No. 4, pp. 351-363.

Justus, G.R. (1991), "Microtel: How "simple” translates into success", The Cornell Hotel and Restaurant Administration Quarterly, Vol. 32 No. 4, pp. 50-54.

Knutson, B.J. (1988), "Frequent travelers: Making them happy and bringing them back", The Cornell Hotel and Restaurant Administration Quarterly, Vol. 29 No. 1, pp. 82-87.

Knutson, B.J., Stevens, P., Patton, M. and Thompson, C. (1993), "Consumers' expectations for service quality in economy, mid-price and luxury hotels", Journal of Hospitality \& Leisure Marketing, Vol. 1 No. 2, pp. 27-43.

Law, R., Buhalis, D. and Cobanoglu, C. (2014). "Progress on information and communication technologies in hospitality and tourism”, International Journal of Contemporary Hospitality Management, Vol. 26 No. 5, pp. 727-750.

Lee, C.C. and Hu, C. (2004), “Analyzing Hotel Customers' E-Complaints from an Internet Complaint Forum”, Journal of Travel \& Tourism Marketing, Vol. 17 No. 2, pp. 167-181.

Leung, D., Rob, L., Hubert V.H. and Dimitrios, B. (2013), "Social media in tourism and hospitality: A literature review", Journal of Travel \& Tourism Marketing, Vol. 30 No. 12 , pp. 3-22.

Levy, S.E., Duan, W. and Boo. S. (2013), “An Analysis of One-Star Online Reviews and Responses in the Washington, DC, Lodging Market", Cornell Hospitality Quarterly, Vol 54 No. 1, pp. 49-63.

Li, H., Ye, Q. and Law, R. (2013), "Determinants of customer satisfaction in the hotel industry: an application of online review analysis", Asia Pacific Journal of Tourism Research, Vol. 18 No. 7, pp. 784-802.

Maddox, R.N. (1981), “Two-factor theory and Consumer Satisfaction: Replication and Extension", Journal of Consumer Research, Vol. 8 No. 1, pp. 97-102.

Marsh, E.E. and White, M.D. (2006). "Content analysis: A flexible methodology", Library trends, Vol. 55 No. 1, pp.22-45.

Matthes, J. and Kohring, M. (2008), "The content analysis of media frames: Toward improving reliability and validity", Journal of Communication, Vol. 58 No. 2, pp. 258-279.

McCarthy, L., Stock, D. and Verma, R. (2010), "How travelers use online and social media channels to make hotel-choice decisions", Cornell Hospitality Reports, Vol. 10 No. 18, pp. 6-18.

Miller, J.A. (1977), "Studying satisfaction, modifying models, eliciting expectations, posing problems, and making meaningful measurements", Conceptualization and measurement of consumer satisfaction and dissatisfaction, pp. 72-91.

Nasution, H.N. and Mavondo, F.T. (2008), "Organisational capabilities: antecedents and implications for customer value”, European Journal of Marketing, Vol. 42 No. 3-4, pp. 477-501. 
O’Connor, P. (2008), “User-generated content and travel: A case study on Tripadvisor.com” In Information and communication technologies in tourism 2008, pp. 47-58. Springer Vienna.

O’Connor, P. (2010), “Managing a hotel's image on TripAdvisor”, Journal of Hospitality Marketing \& Management, Vol. 19 No. 7, pp. 754-772.

Oliver, R.L. (1980), “A cognitive model of the antecedents and consequences of satisfaction Decisions", Journal of marketing research, Vol. 17 No. 4, pp. 460-469.

Oliver, R.L. and Linda, G. (1981), "Effect of satisfaction and its antecedents on consumer preference and intention", Advances in consumer research, Vol. 8 No. 1, pp. 88-93.

Pantelidis, I.S. (2010), "Electronic meal experience: A content analysis of online restaurant Comments”, Cornell Hospitality Quarterly, Vol. 51 No. 4, pp. 483-491.

Poon, W.C. and Low, K.L.T. (2005), “Are travellers satisfied with Malaysian hotels?”, International Journal of Contemporary Hospitality Management, Vol. 17 No. 3, pp. 217227.

Qu, H., Ryan, B. and Chu. R. (2000), "The importance of hotel attributes in contributing to travelers' satisfaction in the Hong Kong Hotel Industry", Journal of Quality Assurance in Hospitality \& Tourism, Vol. 1 No. 3, pp. 65-83.

Schlossberg, H. (1991), "Customer Satisfaction: Not a Fad, but a Way of Life", Marketing News, Vol. 25 No. 20, pp. 18-21.

Sparks, B.A. and Bradley, G.L. (2014), "A "Triple A" Typology of Responding to Negative Consumer-Generated Online Reviews”, Journal of Hospitality \& Tourism Research, 1096348014538052.

Sparks, B.A. and Browning, V. (2011), "The impact of online reviews on hotel booking intentions and perception of trust", Tourism Management, Vol. 32 No. 6, pp. 1310-1323.

Swan, J.E. and Combs, L.J. (1976), "Product performance and consumer satisfaction: a new Concept", The Journal of Marketing, Vol. 40 No. 2, pp. 25-33.

Trip Advisor (2015), "What do star ratings for hotels mean?", Retrieved from https://www.tripadvisorsupport.com/hc/en-us/articles/200614057-What-do-star-ratingsfor-hotels-mean-.

Verma, R., Stock, D. and McCarthy, L. (2012), "Customer preferences for online, social media, and mobile innovations in the hospitality industry", Cornell Hospitality Quarterly, 1938965512445161.

Vermeulen, I.E. and Seegers, D. (2009), "Tried and tested: The impact of online hotel reviews on consumer consideration", Tourism Management, Vol. 30 No. 1, pp. 123-127.

Walls, A., Okumus, F., Wang, Y. and Kwun, D.J.W. (2011), "Understanding the consumer experience: An exploratory study of luxury hotels", Journal of Hospitality Marketing \& Management, Vol. 20 No. 2, pp. 166-197.

Wang, Y. and Fesenmaier, D.R. (2004), "Modeling participation in an online travel community", 
Journal of Travel Research, Vol. 42 No. 3, pp. 261-270.

Xiang, Z. and Gretzel. U. (2010), "Role of social media in online travel information search", Tourism management, Vol. 31 No. 2, pp. 179-188.

Yang, W. and Mattila, A.S. (2012), 'The role of tie strength on consumer dissatisfaction Responses", International Journal of Hospitality Management, Vol 31 No. 2, pp. 399404.

Yim, C.K., Tse, D.K. and Chan, K.W. (2008), "Strengthening customer loyalty through intimacy and passion: roles of customer-firm affection and customer-staff relationships in services", Journal of Marketing Research, Vol. 45 No. 6, pp. 741-756.

Yoo, K.H. and Gretzel, U. (2008). "What motivates consumers to write online travel reviews?”, Information Technology \& Tourism, Vol. 10 No. 4, pp. 283-295. 